\title{
Virtual Cities as a Collaborative Educational Environment
}

\section{Cidades Virtuais como um ambiente educacional colaborativo}

\begin{abstract}
The CIVITAS (Virtual Cities with Technologies for Learning and Simulating) project presents a research, teaching and extension approach directed to the construction of cities imagined by students in the first years of elementary school, with an emphasis to the fourth grade. The teacher ventures on a deviation from the official curriculum proposed to reflect upon the invention of cities along with the children. Within this context, the game Città is introduced as an environment that allows the creation of digita real/virtual/imagined cities, and enables different forms of interaction among the students through networked computers. The cooperative situations, made possible by the access to the game, are tools for teachers and students to think about the information that operate as general rules and words of order with the invention of the city/knowledge.

Keywords: Educational simulation environment. Compu-
\end{abstract} ter-Supported Collaborative Learning. Educational games.

Resumo: O CIVITAS (Cidades Virtuais com Tecnologias para Aprendizagem e Simulação) é um projeto de pesquisa, ensino e extensão, orientado por uma abordagem voltada à construção das cidades imaginadas pelos alunos, nos primeiros anos do ensino fundamental, com ênfase na quarta série. Os professores juntamente com as crianças aventuram-se neste projeto sobre um desvio em relação ao currículo oficial, proposto para refletir sobre a invenção das cidades. Neste contexto, o jogo Città é apresentado como um ambiente que permite a criação de conteúdos digitais, real / virtual / imaginário de cidades, permitindo diferentes formas de interação entre os alunos, por meio de computadores em rede. As situações de cooperação, possibilitadas pelo acesso ao jogo, são ferramentas para professores e alunos poderem pensar as informações que operam como regra geral e palavras de ordem com a invenção da cidade I conhecimento.

Palavras-chave: Ambiente de simulação educacional, Aprendizagem colaborativa apoiada pelo computador, Jogo educativo.
MÜLLER, Daniel Nehme et al. Cities as a Collaborative Educational Environment. Informática na Educação: teoria \& prática, Porto Alegre, v. 12, n. 1, p. 31-38, jan./jun. 2009.
Daniel Nehme Müller
Universidade Federal do Rio Grande do Sul - UFRGS
tto Lopes Braitback de Oliveira
Universidade Federal do Rio Grande do Sul - UFRGS

Joelma Adriana Abrão Remião Universidade Federal do Rio Grande do Sul - UFRGS

Paloma Dias Silveira Universidade Federal do Rio Grande do Sul - UFRGS

Márcio André Rodrigues Martins Universidade Federal do Rio Grande do Sul - UFRGS

Margarete Axt Universidade Federal do Rio Grande do Sul - UFRGS

\section{I ntroduction}

T he exploration of the CITY, its structure and dynamics, in the first years of elementary school in Brazil is often accomplished through a curricular activity of building city models. However, this takes place in a short period of time, usually one or two days, and has the sole purpose of representing urban spaces, such as buildings, roads, public squares and others.

Within the context of the CIVITAS project and its proposal for a continuing development education for working teachers, the city's model is built as an axis of the pedagogical practice. This way, it operates not only as a temporary activity, but also as a mechanism for 
study throughout the school year as well, or while there is reason for its existence.

The city in which the child resides and lives is studied and represented as a municipality in the conventional curriculum; it participates as a memory, as strength of an entire past lived by the child. In our studies, this memory, this entire past, this city in its group of material, living and human relations constitutes the virtual of the cities created by the children (AXT; MARTINS, 2008).

The use of diversified materials, such as cardboard, wood, clay, paint and others (Fig. 1 ), for the child to build collectively, based on his/hers imagination and conversation with fellow classmates, can be considered another curricular activity with planned beginning and end. But the usage of these materials, most of them recyclable, is far from being an activity with an established purpose, because the emphasis is given to the building process, the imagination. Furthermore, there are contents that can be related to the city through its history, economy, geography, geometry, basic sanitation, health system, transportation, social and political relations among others.

In discussion for new research and teaching methodologies for the classroom, the LELIC (Laboratory for Studies in Language, Interaction and Cognition, of the Faculty of Education of the Federal University of Rio Grande do Sul) team proposed a city editing software (the game Città) with which the children could, collectively, build virtual cities with other materials and technologies (like word processors and presentation tools) in the classroom. The opportunity to increase group work with the online interaction between classes, and the possibility to create simulations of other

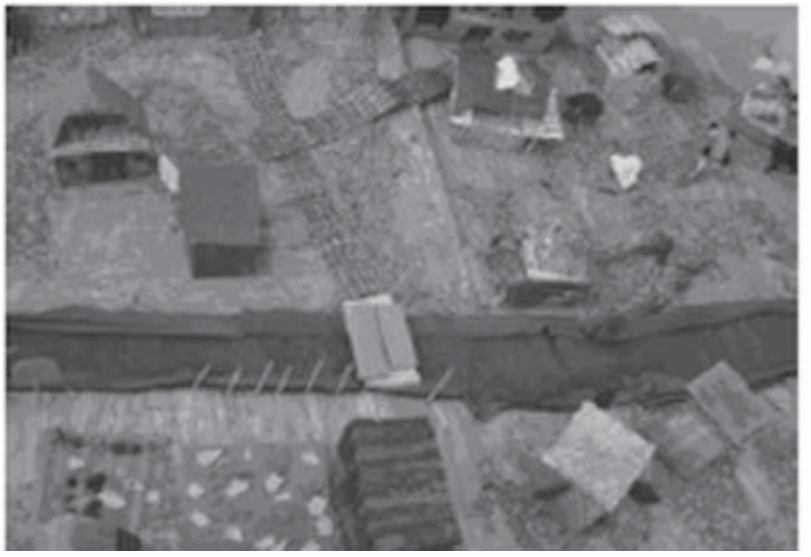

natures (natural or with human intervention events), formed the motivating nucleus in favor of making virtual cities in the most varied ways, including digital technology.

This was the beginning of a partnership between municipal governments, teachers and university, where all counterparts were involved in the creation of pedagogical practices regarding the virtual cities. The LELIC team and teachers worked together, in study and development groups, discussing traditional pedagogical practices and alternatives, considering the challenging world of teaching-learning relations contained in virtual cities as a central axis of this process.

Therefore, Città, the educational game presented here, is a part of the CIVITAS project and it seeks to establish an environment that not only reproduces, but intensifies as well, the inventive possibilities of other city models.

This article will present the CIVITAS project, where the game Città was originated, a view on the technology of educational games, the description of the game and its components, future perspectives and some conclusions.

\section{The CIVITAS Project}

CIVITAS was born from the collaboration and partnership of LELIC-FACED-UFRGS, involving researchers, post-graduate students, undergraduate scholarship students and municipalities from the countryside of the state of Rio Grande do Sul through their schools, teacher, students and managers.

CIVITAS is intended as a project featuring classroom experiments, actively involving te-

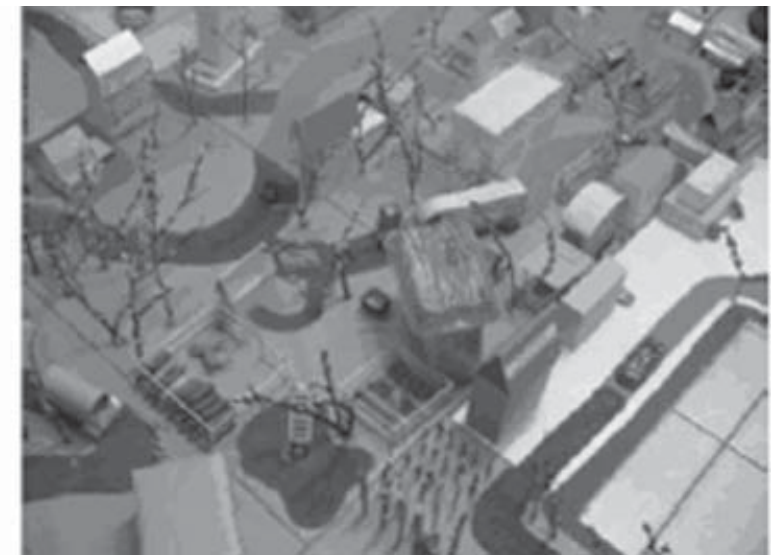

Figure 1 - Pictures of models built by students in the CIVITAS project. 
achers and students in the first years of Elementary School. The project expects to open alternative spaces for doing-thinking-making Virtual Cities, along with teachers and students, from the varied use of multiple technologies available in the classroom, including digital technologies.

From the beginning, the development team and teachers have worked together, discussing the methodological feasibility of the project in the classroom, concurrently to the beginning of the modeling process of the simulation editor Città; thus, before classroom use of the prototype was possible. The meetings with the teachers became systematical and evolved into a work and study group, configuring a continuing development education at the workplace. The group started being more concerned with teaching practices used nowadays and how these practices can be changed, also as a way to prepare the incoming of the simulator in the classroom with safety, as well as other technologies such as digital cameras and camcorders, in a way to avoid these equipments and software from becoming just one more technology without any qualified implication on the educational practice. However, this transformation process is not only a simple substitution of one pedagogical approach for another, there are activities and discussions about the coexistence of several practices in the same classroom, as well as the coexistence of several technologies, from the blackboard and chalk to computers and virtual simulation environments.

The project has the important goal of combining the classroom curricular activity, contents and different methodologies, with the exploration of possibilities in the construction of a virtual city, benefiting the learning process and knowledge. Throughout this work, the teachers considered important a more systematic and deep discussion about the educational challenges emerged from the future insertion of a new technology in the classroom. The description of practices, the identification of common problems, the need of theoretical reading to support the discussions about possible solutions, all this, step by step, led to the breaking up with routine practices and the creation of new lines of action. Just like they did in the study group, teachers began experimenting discussions with the children on how to study the city, how to organize in order to retrieve interesting data, what are interesting data, what was "necessary" to learn about the city they lived in.

The search for information and other elements to support the constructions in the varied levels of the children's interests (the urban infra-structure, the organizational structure, strictly speaking, and its relations with environments such as the natural-social, urbanrural, historical-cultural and so on) started being applied in several modalities. The children participated actively, along with the teachers, in the definition of different search possibilities - visitation, field research, interviews with family members, neighborhood residents and people of the city's public life, research in documents, videos, movies, music, virtual libraries, websites and interactions through virtual learning environments (VLE). The records resulted were according to the children's creativity, especially in written observations, in physical or digital support, pictures and collections of materials, or in an exhibition of objects and relics.

Still without the use of the simulation editor Città, the children's productions, based on the results of their records and research, in this stage, is expressed as follows: (i) through countless and varied ways of artistic productions ; (ii) with descriptions and narratives created over a determined plane of reference, in technical-scientific reports standards, like seminars and results discussion; (iii) or still, in an immanent plan of thought, exercising conceptual construction, unfolding in several and multiple manners of existence bounded by an ethics and aesthetics of respect regarding differences and life (DELEUZE; GUATTARI, 1997).

Furthermore, the schools' computer labs connected to the internet have allowed the children and teachers access to the network. The VLEs have been used with several possibilities and purposes of discussion and research. Since 2004, the project proposed the insertion of technological islands (a set of three computers and a printer) connected to the internet in the classrooms: this device positively confronted the teaching practices with the demand for diversity, difference and multiplicity in the classroom. 


\section{From the Models to the Simulation Editor Città: learning and teaching perspectives}

The CIVITAS Project, while inserted in the classroom context, operates as an articulator of the goals, thematic blocks and contents found in the school curriculum, which is organized according to the National Curricular Parameters (NCPs) for elementary school. Therefore, the project is not a strange element in the teaching activity, but it joins the school daily life and questions how the curriculum contents are treated and developed, suggesting an intense movement of reflection upon the possibilities of creating alternative spaces for the construction of the City, along with teachers and students.

In this perspective, the purpose is not to talk about the introduction of a project in schools as a model to determine the best curriculum or the best way of working in the application of this curriculum. However, what the project proposes is exactly the opposite: not to be regarded as a guideline to be followed, but to refrain the impulse of following an homogeneous ideal, where everyone must learn everything at the same time, and consider the challenge of opening up to instabilities; seeking, in the multiplicity of points of views, for a creative and ingenious insertion of the students in the learning process, finding new (other) ways of seeing, thinking and acting.

From the model to the simulation editor Città there is a set of actions that permits us to invest in the CIVITAS project as a space for thinking the development of the teacher allied to new technologies, without disregarding the treatment given to the technologies that are already a part of the educational environment. Thus, the game Città does not arrive in the school as an accessory, or a technical device to improve planning, but to allow other ways of simulation that were not considered before, offering new possibilities to create the virtual City. Regarding the planning and the way of teaching, besides the flexibility in its use in the classroom and activities, it features another understanding of how knowledge occurs, from the perspective of how the student learns, as well as in how the teacher invests in his/her own development.
Regarding the student's involvement, it is observed that the knowledge occupies a place of pleasure, which exceeds from the simple acquisition of a certain content. To create the City in the model, the student needs, besides skills and cognitive and motor abilities, to know how to work in a team, in order to allow projects emerging in the group to come up and know how to deal with inevitable conflicts. The student also needs to know how to listen, analyze, discuss, stand-up for his/her point of view, find solutions, imagine, create, write, research, seek for information or alternatives. In Città, the interactions are broadened, new challenges are contextualized and other research issues are triggered from the needs that arise in its use in the classroom, joining students, teachers and researchers efforts.

\section{Digital Educational Games}

Città can be classified as a civilization game, where the game allows conquering of space and construction of the necessary infrastructure for the population's survival (HUBER, 2008). However, differently from commercial games, the goal of Città is not the conquering of other nations, but the construction of a city, more similar to Simcity (by Electronic Arts), Caesar or Pharaoh (both by Impressions Games). Nevertheless, Città differs a lot from these because it is a free software, less complex, collaborative and can be adjusted to the curricular educational needs. In other words, Città is a collective game, but without a competitive purpose, based on a constructive logic of cooperation and collaboration.

Digital games are precious instruments for education, because it is an attraction for children and teenagers. According to Mysirlaki and Paraskeva, many basic principles of the social cognitive theory can be found in digital games, because they influence behavioral models, repetitive behaviors and construction of the imaginary, among other factors (MYSIRLAKI; PARASKEVA, 2007). After the examination of several commercial games, Mysirlaki and Paraskeva recommended the creation of networked educational simulation games, which meets exactly the purpose of Città.

Along this line, Stone and Gutiérrez used 
games to guide the learning process and explained how the computer can intercede in the solution of problems in a teaching environment (STONE; GUTIÉRREZ, 2007). In their work, Stone and Gutiérrez (2007) try to generate, through the educational game, a continuing redefinition of the object being studied by the student, where the teacher, instead of performing an analysis or previous orientation of the knowledge, acts as a collaborator in a process of discovery mediated by the computer. It is possible to say that the game Città is in sync with this kind of practice, because it intends to be a mediator in the process of discovery and, especially, of creation and shared knowledge construction.

The computer as a teaching tool of the 21st century is defended by Spires, Lee and Lester, who say that the new ways of work, communication and knowledge organization involve the computer as a means of communication between people (SPIRES; LEE; LESTER, 2008). They also report that network games stimulate reasoning and the elaboration of strategies, besides the organization of virtual social interaction between the players. In this sense, being Città a multiplayer game, it provides an environment for social interaction in the virtual space, demanding the elaboration of rules to guide the players involved in the construction of the city.

According to Rieber, the act of playing is associated with several interactive activities and has an important role in mental and social development (RIEBER, 2007). In the digital educational game, when the playing appears involved with the micro-worlds and simulations environments, this role can be reinforced by the interaction with other people.

Therefore, multiplayer digital games allow the participation of more than one player at the same time and enable the occurrence of direct or indirect interactions among players, generally in the form of competition, cooperation or collaboration (MANNINEN, 2002). Regarding digital multiplayer educational games, they present the same features of educational systems that can be used to promote Computer-Supported Collaborative Learning (CSCL).

The CIVITAS project focuses on collaborative educational games and is based on the CSCL definitions proposed by Dillenbourg (1999), who defines a collaborative learning activity as one with the purpose of sharing an understanding or solving a problem. In this case, understanding refers to the actions and strategies developed by the players; and the problem refers to, collectively, winning or bypassing the challenges and obstacles presented by the educational game. For instance, when one of the CIVITAS teachers suggests a task to be done with Città, he/she imposes resource limitations or conflicting tasks that need to be solved by the players. From the interaction among the students, as Città users, we have a favorable context for socialization, cooperation and learning processes, when the students work to solve problems and overcome limitations imposed by the simulator program.

\section{The Città Game}

As mentioned in the previous section, Città is a collaborative educational game, aimed at a collective construction involving cooperative and negotiating actions. To enable the simulation of cities with this collaborative format, Città was developed in Java language, specially for children's tridimensional (3D) modeling of cities guided by their teachers. To speed up the application development, an OpenGL Graphic Engine API, developed by Jouvieje and available in its website, is being used (JOUVIEJE, 2008). It offers countless graphic resources, compatible with J OGL, LWJ GL, GL4JAVA and it is distributed under a GNU license. The multiplayer resources are developed with the Java's RMI (Remote Method Invocation) command. The game's architecture was conceived under the MVC (Model-View-Controller) project standard, which solves the dependency problems between data and application interface with the separation of the development in: data model, business logic and user interface. Moreover, Città is a multiplayer game and should, therefore, provide resources to enable a real time construction by various authors on the city's elements, in a way to simulate the interaction in an actual physical model of cardboard or clay.

Each group of children can build its tridimensional virtual city in Città, from the topographic mapping through the Mappa component, to the layout of rivers and streets and the localization of constructions, as well as 
color customization through the Edittore component. The game still include the intelligent assistant Maga Vitta to alert about ecological events in the city.

Initially, the game offers only a plain terrain over which the terrain's topography modeling will be applied. With the Mappa component, the student can create hills, mountains and many other sorts of elevations where the city will be built.

The user chooses the sector (tile) to alter and selects its total elevation or one of the four sides to proceed with the inclination. Over the relief generated, the student can create roads and rivers. For such, it is possible to select the kind of path or the water to create lakes, rivers, etc. An example of the effect created with the terrain inclination can be seen in Fig. 2 .

The coherent organization of constructions is the first goal of Città. The city authors can create the structures they judge necessary freely and place them over the terrain. The constructions available are: house, building, church, city hall, factory, market, school and farm (for the rural zone).

To start creating, all the student needs to do is click on the button construir (build), then on the button corresponding to the image of the structure desired and place it on the terrain. After being created, each structure occupies a space in tiles, according to its size, and has a set of properties.

Just like in a physical model, the constructions can be painted in different colors. On selecting a structure, the Edittore component allows the possibility of changing its color, as well as write the history related to its creation. These resources can be accessed within the set of properties of each structure. To enable the color customization and maintain the texture, the multi-texture technique (BLYTHE, 1999) was used, making it possible to use several textures on the 3D object at the same time.

The Maga Vitta assistant is an intelligent agent designed to be the ecological regulator in Città (AXT; LONGHI; SILVEIRA; GUIMARÃES, 2008). During the game, according to the user's actions, some factors can occur, such as signs of pollution around certain constructions, among others. For example, around a factory, the terrain will become more polluted over time, as shown in the dark area in Fig. 2.

The actions of the Maga Vitta agent develop around four axes: nature, water, energy and population. In the nature axis, which is still under development, the air, water and land pollution aspects should be evaluated. In the other axes, the evaluation will be on: the water contamination, waste and supply; the illumination and use of electric devices; and the monitoring of the population size and its relation with the infra-structure. The agent interacts with the user through alerts, with the intention to promote the discussion about critical situations that can be hazardous to the city population.

\section{Conclusions}

Since its beginning in 2003 until today, the CIVITAS project has been discussing in an increasingly deeper way the teaching-learning processes involved with the interactions in the construction of city models - the virtual cities. In this sense, the digital collaborative educational game Città is used as a virtual model,
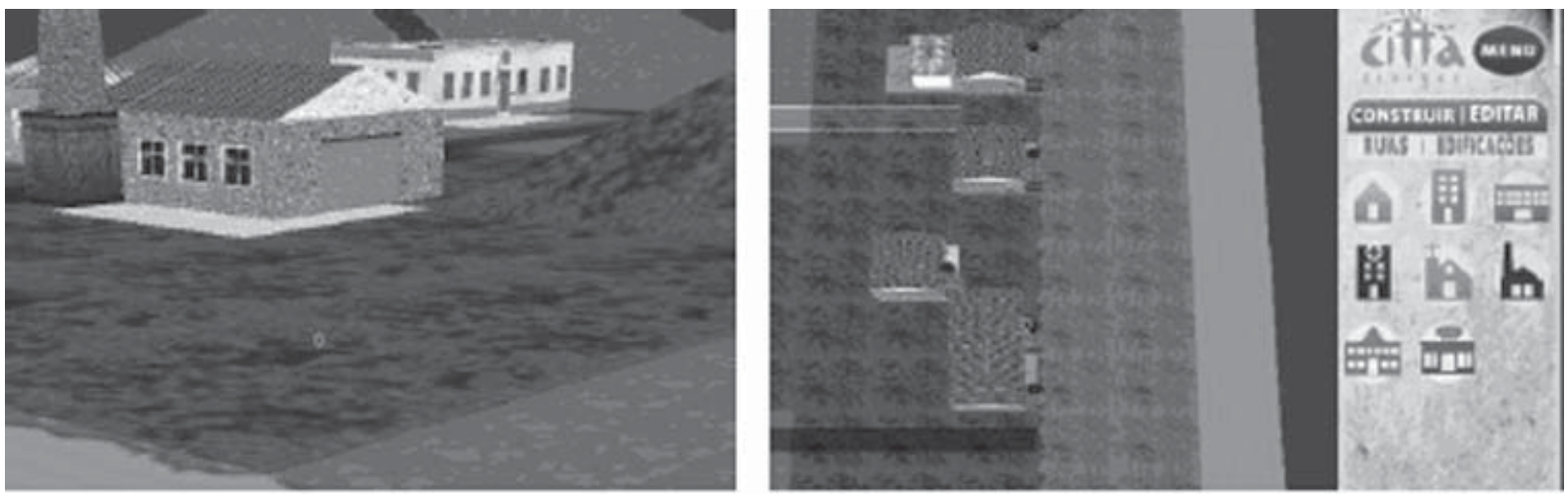

Figure 2 - Images od the pollution effect (dark in the terrain). 
and creates a new challenging environment, both for educators and students.

Città is based on civilization games, but its goal is to be a environment for collaboration among the several simultaneous players. Therefore, the city can be constantly built and modified, demanding from the teacher the elaboration of challenges for the students and the promotion, among them and with them, of the construction of knowledge and mutual managing of the city's priorities as a whole, aiming at its survival.

It is also important to mention that Città is an educational game not developed for the teachers, but with them and based on their needs and reality. It is not intended to be, like commercial games, a product for mass use, but a means for innovation of teaching methodologies and pedagogical practices in earlier grades/classes. The project is evalu- ated weekly by the teachers involved, along with the University team, in meetings at the schools.

The project results, as a whole, are presented once a year by the teachers participating in the project, in an event of shared evaluation, along with the University team and guests. This year the children suggested a "kids seminar", to present their experiences to parents and interested public, which shows how they are building their place as studentsresearchers.

Città is not finished yet; it is still under development and it may never be concluded because it is a game under constant construction and reconstruction. Besides following the natural technological evolution, it will also attend to the needs - in constant growth - of students and teachers in a globalized world.

\section{Acknowledgements}

Until 2007, the CIVITAS project has counted on the support of CNPq - National Council of Scientific and Technological Development. Today, it counts on the funding of FINEP - Funding Institution for Studies and Projects. We thank the support in the forms of partnerships, assistances and sponsorships from: Faculty of Education - FACED/UFRGS; Post-Graduate Course in Education - PPGEDU/ UFRGS; Post-Graduate Course in Computer Science Applied in Education - PPGIE/UFRGS; Interdisciplinary Center for New Technologies in Education - CINTED/UFRGS; Vale do Rio Pardo Municipalities Association - AMVARP; Federation of Municipal Associations of Rio Grande do Sul - FAMURS; Municipal Government of Venâncio Aires/RS; Municipal Government of Mato Leitão/RS; Municipal Government of Sobradinho/RS; Municipal Government of Cruzeiro do Sul/RS.

\section{References}

AXT, M. CIVITAS: abrindo espaços de invenção na escola (CIVITAS: opening spaces for invention in school). In: MOLL, J. (Ed.). Múltiplos Alfabetismos: diálogos com a escola na formação de professores (Multiple literacy: dialogues with the school in teacher education). Porto Alegre: UFRGS, 2005. P. 17-40.

AXT, M.; LONGHI, M.; SILVEIRA, P.D.; GUIMARÃES, L.N. Maga Vitta: conversational ecological agent in an interactive collective construction environment for basic education. In: VICCARI, R.M.; JAQCQUES, P.; VERDIN, R. (Ed.). Intelligent Agents for Education. London: Information Science Reference (IGI Global), 2008. P. 73-95.

AXT, M.; MARTINS, M.A.R. Coexistir na diferença: de quando a formação em serviço pensa modos de habitar a sala de aula (Coexist in the difference: when the training in service think ways to inhabit the classroom) In: TRINDADE, I ole Maria Faviero. (Ed.). Múltiplas Alfabetizações e Alfabetismo (Multiple literacies and literacy). Porto Alegre: Ed. da UFRGS, 2008. V. 1, p. 133-158.

BLYTHE, D. Advanced Graphics Programming Techniques Using OpenGL: SIGGRAPH` 99 Course. 1999. Available at: <http://www.opengl.org/resources/code/samples/sig99/advanced99/notes/notes.html> Accessed: nov. 2008 
DELEUZE, G.; GUATTARI, F. Mil Platôs: capitalismo e esquizofrenia (One thousand plateaus: capitalism and schizophrenia). São Paulo: Ed. 34, 1997.

DILLENBOURG, P. What do you mean by collaborative learning? In: DILLENBOURG, P. (Ed.). Collaborative Learning: Cognitive and Computational Approaches. Amsterdam: Elsevier Science/Pergamon, 1999. P. 1-19.

HUBER, N. Coming Attractions. School Library Journal, New York, v. 54, no. 5, pp. 38-39, may 2008.

JOUVIEJE, J. OpenGL Graphic Engine API. 2008. Available at: <http://jerome.jouvie.free.fr/OpenGl/Projects/ GraphicEngine.php> Accessed: aug. 2008.

MANNINEN, T. Towards Communicative, Collaborative and Constructive Multiplayer Games. In: COMPUTER GAMES AND DIGITAL CULTURES CONFERENCE, 2002, Tampere, Finland. Proceedings... Tampere: Tampere University Press, 2002. P. 155-169.

MYSIRLAKI, S.; PARASKEVA, F. Digital games: Developing the I ssues of Socio-cognitive Learning Theory in an Attempt to Shift an Entertainment Gadget to an Educational Tool. In: INTERNATIONAL WORKSHOP ON DIGITAL GAME AND INTELLIGENT TOY ENHANCED LEARNING - DIGITEL ‘07, 1., 2007, J hongli, Taiwan. Proceedings... Los Alamitos: IEEE Computer Society, 2007. P. 147-151.

RIEBER, L.P. Seriously considering play: Designing interactive learning environments based on the blending of microworlds, simulations and games. Educational Technology Research \& Development, Washington, v. 44, n. 2, p. 43-58, 2007.

SPIRES, H.A.; LEE, J.K.; LESTER, J. The Twenty-First Century Learner and Game-Based Learning. Meridian: a Middle School Computer Technologies J ournal, Raleigh, NC, v. 11, no. 1, p. 1-4, Winter 2008.

STONE, L.D.; GUTIÉRREZ, K.D. Problem articulation and the processes of assistance: An activity theoretic view of mediation in game play. International J ournal of Educational Research, Oxford, v. 46, n. 1/2, p. 4356, 2007.

Recebido em janeiro de 2009.

Aprovado para publicação em abril de 2009

\section{Daniel Nehme Müller}

Laboratório de Estudos em Linguagem, Interação e Cognição (LELIC), Faculdade de Educação (FACED), Pós-Graduação em Educação (PPGEDU), Universidade Federal do Rio Grande do Sul (UFRGS) - danielnm@inf.ufrgs.br

\section{Otto Lopes Braitback de Oliveira}

Laboratório de Estudos em Linguagem, Interação e Cognição (LELIC), Faculdade de Educação (FACED), Pós-Graduação em Educação (PPGEDU), Universidade Federal do Rio Grande do Sul (UFRGS) - ottolb@gmail.com

\section{oelma Adriana Abrão Remião}

Laboratório de Estudos em Linguagem, Interação e Cognição (LELIC), Faculdade de Educação (FACED), Pós-Graduação em Educação (PPGEDU), Universidade Federal do Rio Grande do Sul (UFRGS) - jremiao@brturbo.com.br

\section{Paloma Dias Silveira}

Laboratório de Estudos em Linguagem, Interação e Cognição (LELIC), Faculdade de Educação (FACED), Pós-Graduação em Educação (PPGEDU), Universidade Federal do Rio Grande do Sul (UFRGS) - paloma.dias@gmail.com

\section{Márcio André Rodrigues Martins}

Laboratório de Estudos em Linguagem, Interação e Cognição (LELIC), Faculdade de Educação (FACED), Pós-Graduação em Educação (PPGEDU), Universidade Federal do Rio Grande do Sul (UFRGS) - mmartins2006@gmail.com

\section{Margarete Axt}

Laboratório de Estudos em Linguagem, Interação e Cognição (LELIC), Faculdade de Educação (FACED), Pós-Graduação em Educação (PPGEDU), Universidade Federal do Rio Grande do Sul (UFRGS) - maaxt@ufrgs.br 